\title{
PENGARUH KEPEMIMPINAN TRANSFORMASIONAL TERHADAP KINERJA PEGAWAI BAGIAN KEUANGAN SEKRETARIAT DAERAH KABUPATEN CIAMIS
}

\author{
R. Hari Busthomi Ariffin \\ Program Studi Administrasi Negara \\ Fakultas Ilmu Sosial Dan Ilmu Politik Universitas Pasundan \\ hari.busthomi@unpas.ac.id
}

DOI: http://dx.doi.org/10.23969/decision.v1i2.1817

\begin{abstract}
Undang-Undang Nomor 23 tahun 2014 concerning Regional Government, each regional government is given space and authority to regulate and manage its own government affairs. Leadership is a matter that really needs to be considered in organizing an organization / government. Transformational leadership is a leader who is able to be a motor of change (transformation) in order to create a good form of cooperation and create a harmonious work environment by mastering the vision, mission and goals of the organization, so as to optimize employee performance in achieving organizational goals. There are several factors of the lack of influence of Transformational Leadership on Employee Performance in the Finance Section of the Ciamis Regency Secretariat, namely: 1. The leader is not optimal in giving attention to all employees so that they work optimally.2. Human resources are less capable and less competent in carrying out their duties. 3. Work pressure is internal pressure that can hamper employee performance. The fact is theoretically related to the non-optimal implementation of Transformational Leadership in the Finance Section of the Ciamis Regency Secretariat based on the principles of Idealized influence, Intellectual stimulation, Inspiration motivation, Individualized consideration. Thus the problems mentioned above relating to Transformational Leadership will affect the improvement of Employee Performance in the Finance Section of the Ciamis District Secretariat, and will affect both directly and indirectly on the effectiveness of government administration and improvement of excellent public services to the public.
\end{abstract}

Keyword: leadership, transformational, performance

\begin{abstract}
ABSTRAK
Undang-Undang Nomor 23 tahun 2014 tentang Pemerintah Daerah, setiap pemerintah daerah diberi ruang dan kewenangan untuk mengatur dan mengurus sendiri urusan pemerintahannya. Kepemimpinan merupakan hal yang sangat perlu diperhatikan dalam penyelenggaraan organisasi/pemerintahan. Kepemimpinan transformasional merupakan pemimpin yang mampu menjadi motor penggerak perubahan (transformation) guna menciptakan bentuk kerjasama yang baik dan menciptakan lingkungan kerja yang harmonis dengan menguasai visi, misi dan tujuan organisasi, sehingga mampu mengoptimalkan kinerja pegawai dalam mencapai tujuan organisasi. Ada beberapa faktor kurangnya pengaruh Kepemimpinan Transformasional terhadap Kinerja Pegawai pada Bagian Keuangan Sekretariat Daerah Kabupaten Ciamis, yaitu: 1. Pemimpin belum optimal dalam memberikan perhatian kepada seluruh pegawainya agar bekerja secara optimal. 2. Sumber daya manusia yang kurang cakap dan kurang kompeten dalam melakukan tugasnya. 3. Tekanan kerja yaitu tekanan internal yang dapat
\end{abstract}


menghambat kinerja pegawai. Fakta tersebut secara teoritis berkaitan dengan belum optimalnya penerapan Kepemimpinan Transformasional di Bagian Keuangan Sekretariat Daerah Kabupaten Ciamis berdasarkan prinsip Idealized influence, Intellectual stimulation, Inspiration motivation, Individualized consideration. Dengan demikian masalah-masalah tersebut di atas berkaitan dengan Kepemimpinan Transformasional akan mempengaruhi peningkatan Kinerja Pegawai di Bagian Keuangan Sekretariat Daerah Kabupaten Ciamis, serta akan berpengaruh baik secara langsung maupun tidak langsung terhadap efektivitas penyelenggaraan pemerintahan dan peningkatan pelayanan publik yang prima kepada masyarakat.

\section{Kata Kunci: Kepemimpinan, Transformasional, kinerja}

\section{PENDAHULUAN}

Sumber daya manusia merupakan suatu hal yang sangat penting dalam organisasi atau pemerintahan guna mencapai tujuan yang telah ditentukan, keefektifan dan keunggulan organisasi sangat tergantung pada kualitas sumber daya manusia yang dimilikinya. Tersedianya kualitas sumber daya manusia yang tinggi dalam suatu organisasi akan menunjukkan kemampuan kinerja yang lebih baik.

Salah satu unsur penting dalam meningkatkan kinerja pegawai yaitu kepemimpinan. Kepemimpinan merupakan suatu proses mempengaruhi, mengarahkan, mengembangkan sumber daya manusia yang ada, dalam rangka mencapai tujuan organisasi. Maju mundurnya suatu organisasi/ pemerintahan tergantung dari pimpinan organisasi/ pemerintahan tersebut dalam menjalankan/ melaksanakan kepemimpinannya.

Organisasi memerlukan pemimpin reformis yang mampu menjadi motor penggerak perubahan (transformation) guna menciptakan bentuk kerjasama yang baik antara pimpinan dan bawahan, dengan harapan dapat menciptakan lingkungan kerja yang harmonis. Pemimpin yang baik mampu menciptakan kondisi tersebut, dan melakukan pembinaan pegawai, juga memotivasi pegawai sehingga tujuan organisasi dapat tercapai. Kepemimpinan transformasional merupakan kemampuan pemimpin dalam mewujudkan hal tersebut dengan menguasai visi, misi dan tujuan organisasi, sehingga mampu mengoptimalkan kinerja pegawai dalam mencapai tujuan organisasi. Bentuk kepemimpinan ini dianggap efektif dalam mengimbangi situasi, budaya, pola pikir maupun paradigma baru.

Undang-Undang Nomor 23 tahun 2014 tentang Pemerintah Daerah, setiap pemerintah daerah diberi ruang dan kewenangan untuk mengatur dan mengurus sendiri urusan pemerintahannya. Sekretariat Daerah merupakan unsur dalam membantu pemerintah daerah, yang dipimpin oleh sekretaris daerah (SEKDA). Sekretaris daerah bertugas membantu kepala daerah dalam menyusun kebijakan dan mengkoordinasikan dinas daerah, dan lembaga teknis daerah.

Bagian Keuangan Sekretariat Daerah mempunyai tugas pokok dan fungsi membuat laporan keuangan Sekretariat Daerah dalam bentuk Laporan Kinerja Instansi Pemerintah (LKIP) dari seluruh kegiatan, dan pembuatan laporan aset Sekretariat Daerah berdasarkan Peraturan Pemerintah Nomor 58 tahun 2005 tentang Pengelolaan Keuangan Daerah.

Kinerja sektor publik merupakan hasil kerja yang dicapai oleh aparatur pemerintah, baik secara individu, kelompok maupun intitusi sesuai dengan visi, misi, dan tujuan yang telah 
ditetapkan. Kinerja pegawai merupakan hasil kerja pegawai sesuai ketentuan dan capaian dari tujuan yang telah ditetapkan sebelumnya berkaitan dengan visi dan misi dan tujuan organisasi. Dengan demikian pengukuran kinerja perlu dilakukan dalam menilai keberhasilan atau kegagalan sebuah organisasi/pemerintahan.

Berdasarkan hasil pengamatan pada Bagian Keuangan di Sekretariat Daerah Kabupaten Ciamis, ditemukan permasalahan yang berkaitan dengan kinerja pegawai masih rendah. Indikasi ini ditunjukkan dari pimpinan yang belum optimal memberikan pengetahuan, bimbingan, arahan, pelatihan dan dorongan kepada pegawai dalam melaksanakan pekerjaaannya. Hal tersebut perlu untuk diperhatikan oleh pimpinan guna meningkatkan kemampuan dan kompetensi pegawainya, yang kemudian akan menumbuhkan motivasi dan inisiatif para pegawai sehingga menciptakan lingkungan kerja yang harmonis.

Fenomena diatas menunjukan betapa pentingnya pengaruh kepemimpinan transformasional terhadap kinerja pegawai pada Bagian Keuangan Sekretariat Daerah Kabupaten Ciamis. Untuk itu peneliti beranggapan bahwa hal tersebut perlu untuk diteliti lebih lanjut dan dituangkan dalam judul "Pengaruh Kepemimpinan Transformasional Terhadap Kinerja Pegawai Pada Bagian Keuangan Di Sekretariat Daerah Kabupaten Ciamis".

\section{Kerangka Pemikiran}

Berdasarkan masalah-masalah di atas, dalam memecahkan masalah terkait Pengaruh Kepemimpinan Transformasional Terhadap Kinerja
Pegawai di Bagian Keuangan Sekretariat Daerah Kabupaten Ciamis, peneliti mengemukakan teori-teori yang berhubungan sebagai berikut :

Definisi

Kepemimpinan

Transformasional menurut Burns (Pasolog, 2008:129), mengemukakan "Kepemimpinan Transformasional sebagai proses yaitu para pemimpin dan pengikut saling meningkatkan motivasi dan moralitas yang lebih tinggi".

Definisi tersebut menjelaskan bahwa kepemimpinan transformasional adalah dimana para pemimpin memotivasi bawahan, meningkatkan kinerja para pegawai, moralitas yang lebih tinggi dan mempunyai peran sentral serta strategi dalam membawa organisasi mencapai tujuannya.

Menurut Avolio (2004), karakteristik Kepemimpinan Transformasional sebagai berikut:

1. Idealized influence (pengaruh yang di idealkan) adalah sifat-sifat keteladanan atau karisma (role mode) yang ditujukan kepada para pengikut dari pemimpinnya. Faktor karisma mendeskripsikan orang yang khusus dan yang ingin membuat orang lain mengikuti visi yang mereka utarakan. Mereka memberi pengikut visi dan pemahaman akan misi.

2. Intellectual stimulation (rangsangan intelektual), kepemimpinan yang merangsang pengikut atau para pegawai untuk bersikap kreatif dan inovatif serta merangsang keyakinan dan nilai mereka sendiri. Pegawai merasa bahwa pemimpin mendorong pegawai untuk memikirkan kembali cara kerja, untuk mencari cara-cara baru dalam melaksanakan tugas. 
3. Inspiration motivation (motivasi yang menginspirasi), pemimpin dalam hal ini mengkomunikasikan,

menginspirasi mereka lewat motivasi untuk mencapai tujuan organisasi tersebut. Pemimpin menggunakan simbol dan daya tarik emosional untuk memfokuskan upaya bawahan, guna mencapai lebih daripada yang akan mereka lakukan untuk kepentingan pribadi mereka.

4. Individualized consideration (pertimbangan individu), pegawai merasa diperhatikan dan diperlukan secara khusus oleh pemimpin, pemimpin bersedia mendengarkan dan memperhatikan aspirasi dari bawahan atau pegawainya. Pemimpin memperlakukan setiap bawahan sebagai seorang pribadi dengan kecakapan, kebutuhan, dan keinginan masing-masing.

Menurut Mangkunegara dikutip Satibi (2012:103) dalam bukunya Manajemen Publik Dalam Prespektif Teoritik dan Empirik yang menterjemahkan kinerja pegawai sebagai: "Hasil kerja secara kualitas dan kuantitas yang dicapai oleh seorang pegawai dalam melaksanakan tugasnya sesuai dengan tanggung jawab yang diberikan kepadanya".
Dari definisi diatas menjelaskan bahwa kinerja adalah hasil kerja untuk menentukan kualitas dan kuantitas dari hasil kerja tersebut yang dilakukan oleh seseorang untuk melaksanakan fungsi dalam pencapaian tujuan yang telah ditetapkan.

Faktor yang mempengaruhi kinerja menurut Armstrong dan Baron yang dikutip Sedarmayanti (2011:223) antara lain :

1. Personal Factors ditujukan dengan tingkat keterampilan, kompetensi yang dimiliki, motivasi, dan komitmen individu

2. Leadership Factor ditentukan kualitas dorongan bimbingan dan dukungan yang dilakukan manajer

3. Team Factors ditujukan kualitas dukungan yang diberikan rekan kerja

4. System Factors ditujukan adanya sistem kerja dan fasilitas yang diberikan organisasi

5. Contextual atau Situasional Factors ditujukan tingginya tingkat tekanan lingkungan internal dan eksternal

Berdasarkan teori di atas peneliti menyimpulkan bahwa ada hubungan antara kepemimpinan transformasional terhadap kinerja pegawai:

Gambar 1.1

Paradigma Pemikiran tentang Kepemimpinan Transformasional terhadap Kinerja Pegawai

Karakteristik

Kepemimpinan

Transformasional:

1. Idealized influence

2. Intellectual stimulation

3. Inspiration motivation

4. Individualized consideration

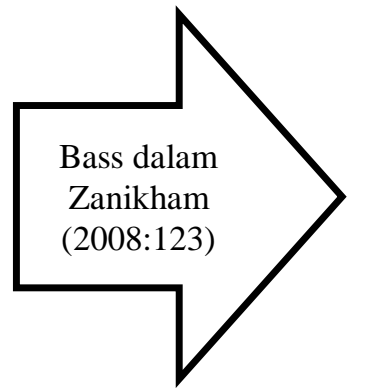

Meningkatkan Kinerja Pegawai

1. Personal Factors

2. Leadership Factor

3. Team Factors

4. System Factor

5. Contextual atau Situasional Factors

Sumber: Armstrong dan Baron yang dikutip Sedarmayanti (2011:223) 
Hal ini diperkuat dengan pendapat dari Bass dalam Zanikham (2008:123): Kemampuan pemimpin mengubah kemampuan kerja, motivasi kerja, dan pola kerja, serta nilai-nilai kerja yang dipersepsikan bawahan sehingga mereka lebih mampu mengoptimalkan kinerja untuk mencapai tujuan organisasi.

Definisi tersebut menunjukkan bahwa kepemimpinan berkaitan dengan kinerja, dikemukakan bahwa kepemimpinan merupakan faktor utama dalam meningkatkan kinerja pegawai, pemimpin yang dapat memotivasi dan mendorong bawahan akan mampu mengoptimalkan kinerja bagi organisasi.

\section{Hipotesis}

Dari penjelasan kerangka pemikiran di atas, peneliti menduga "Adanya Pengaruh Kepemimpinan Transformasional Terhadap Kinerja Pegawai Di Bagian Keuangan Sekretariat Daerah Kabupaten Ciamis". Hipotesis diatas sifatnya verbal dan subtantif artinya belum bisa diuji, oleh karena itu harus diterjemahkan ke dalam hipotesis paradigma yang sudah operasional sebagai berikut:

Keterangan:

$\mathrm{X}=$ Kepemimpinan Transformasional $\mathrm{Y}=$ Kinerja Pegawai

$\varepsilon=$ Diluar variabel Pengaruh Kepemimpinan Transformasional yang tidak diukur tapi dapat mempengaruhi variabel Kinerja Pegawai

\section{Hasil Penelitian}

Hasil penelitian Kepemimpinan Transformasional terhadap Kinerja Pegawai pada Bagian Keuangan Sekretariat Daerah Kabupaten Ciamis
1. Ho adalah pernyataan yang menunjukkan tidak ada perubahan Ho : $\rho \mathbf{s}=\mathbf{0}$, Artinya Ho diduga tidak ada pengaruh antara Kepemimpinan Transformasional (X) dengan Kinerja Pegawai (Y) Bagian Keuangan Di Sekretariat Daerah Kabupaten Ciamis

2. Hipotesis Penelitian adalah pernyataan dari apa yang diharapkan akan terjadi

Hi : $\boldsymbol{\rho s} \neq \mathbf{0}$, Artinya diduga ada pengaruh hubungan antara Kepemimpinan Transformasional (X) dengan Kinerja Pegawai (Y) Bagian Keuangan Di Sekretariat Daerah Kabupaten Ciamis

3. Berikut ini peneliti uraikan paradigma penelitian:

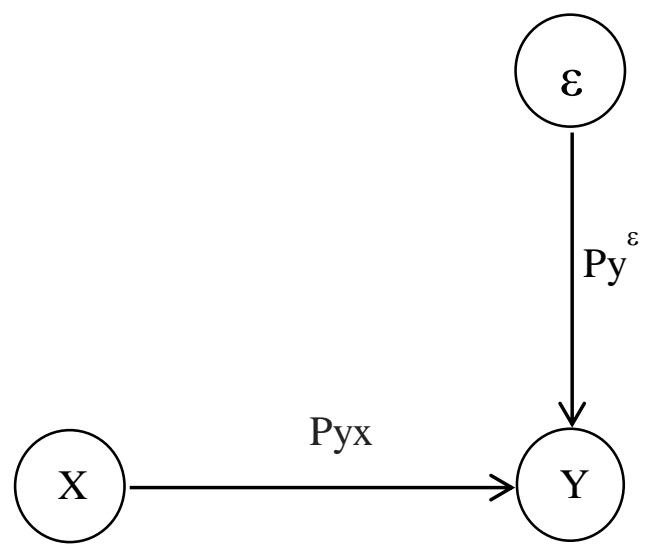

Gambar 1.2 Paradigma Penelitian

Pyx $=$ Pengaruh Kepemimpinan Transformasional terhadap Kinerja Pegawai

$\mathrm{Py}^{\varepsilon}=$ Pengaruh variabel lain diluar penelitian Kepemimpinan Transformasional terhadap Kinerja Pegawai. dari perhitungan analisis regresi linier, yaitu:

1. Berdasarkan kriteria interpretasi koefisien determinan menunjukkan bahwa kepemimpinan transformasional memiliki pengaruh terhadap 
kinerja pegawai di Bagian Keuangan Sekretariat Daerah Kabupaten Ciamis yaitu sebesar $73,8 \%$

2. Hasil persamaan regresi linier menunjukkan bahwa $\mathrm{Y}=6.006+$ $958 \mathrm{X}$, dimana $\mathrm{Y}=$ kinerja pegawai dan $\mathrm{X}=$ Kepemimpinan transformasional koefisien regresinya 0,738 menunjukkan bahwa prediksi kepemimpinan transformasional terhadap kinerja pegawai positif yang artinya bahwa kepemimpinan transformasional terhadap kinerja pegawai berpengaruh

3. Berdasarkan hasil hitung dengan menggunakan program SPSS maka diperoleh tingkat signifikansi yaitu 0,000 , tingkat signifikan $0,000<0,05$ maka hipotesis di tolak yang artinya model regresi ini bisa digunakan untuk memprediksi nilai Y, maka nilai X dan Y sebesar 0,958

Kepemimpinan transformasional berpengaruh besar terhadap kinerja pegawai dengan nilai $73,8 \%$, jika ada faktor lain yang tidak dapat diukur tidak mempunyai pengaruh yang berarti terhadap kinerja.

\section{Kesimpulan}

Kepemimpinan sebagai salah satu faktor penting yang dapat mempengaruhi suatu organisasi. Kepemimpinan merupakan seorang pemimpin mengarahkan, memberikan motivasi lebih, bekerjasama antara bawahan, menggerakkan, mempengaruhi orang lain atau bawahan dan bekerja produktif agar mencapai tujuan yang telah ditetapkan sebelumnya. Sedangkan Kinerja pada sektor publik, pada hakikatnya merupakan hasil kerja yang dicapai oleh aparatur pemerintah secara individu dan institusi pemerintah secara kelembagaan sesuai dengan visi, misi, dan tujuan yang telah ditetapkan sebelumnya.

Berdasarkan hasil penelitian dan pembahasannya, mengenai pengaruh Kepemimpinan Transformasional terhadap Kinerja Pegawai pada Bagian Keuangan Sekretariat Daerah Kabupaten Ciamis, peneliti mengambil kesimpulan bahwa adanya kepemimpinan transformasional sangat mempengaruhi terhadap kinerja pegawai. Pengaruhnya sangat positif dan signifikan dan berkontribusi dalam pencapaian kinerja pegawai pada Bagian Keuangan Sekretariat Daerah Kabupaten Ciamis.

Peneliti menyimpulkan bahwa kepemimpinan transformasional terhadap kinerja pegawai sangat berpengaruh terhadap kinerja pegawai terlihat dari kriteria interpretasi koefisien determinan menunjukkan kepemimpinan transformasional memiliki pengaruh terhadap kinerja dengan nilai sebesar $73,8 \%$. Dengan uji regresi yang dilakukan peneliti melalui program SPSS bahwa kepemimpinan transformasional terhadap kinerja pegawai signifikansi yaitu 0,000 karena $0,000<0,05$ berarti hipotesis dari yang peneliti duga bahwa hipotesis antara kepemimpinan transformasional tidak ada pengaruh dan hipotesis penelitiannya benar yaitu adanya pengaruh kepemimpinan transformasional terhadap kinerja.

Uji reliabilitas di antara keduanya yaitu kepemimpinan transformasional dan kinerja pegawai keduanya mempunyai nilai reliabilitas > 0,06, kepemimpinan transformasional mempunyai nilai 0,906 sedangkan kinerja pegawai mempunyai nilai 0,882. Dan Penghitungan skor sikap responden terhadap kepemimpinan transformasioanl dan kinerja pegawai kategori diantara tinggi dan tertinggi bahwa sikap responden terhadap kinerja pegawai di kategorikan dalam diagram 
kuartil yang ditunjukkan pada hasil penelitian pada gambar 4.1 dan gambar 4.2 yaitu diantara tinggi dan tertinggi.

Kepemimpinan transformasional mempengaruhi kinerja pegawai pada Bagian Keuangan Sekretariat Daerah Kabupaten Ciamis, dengan nilai koefisien determinasi sebesar 73,8\% dengan tingkat epsilon sebesar $26,2 \%$.

A. Hambatan-Hambatan dalam Pelaksanaan Kepemimpinan Transformasional Terhadap Kinerja Pegawai pada Bagian Keuangan Sekretariat Daerah Kabupaten Ciamis

Organisasi ataupun instansi pemerintah tidak selamanya melaksanakan pekerjaan selalu tepat dan sesuai yang direncakan, pastinya ada hambatanhambatan terhadap kinerja pegawai yang membuat kinerja pegawai tidak optimal dan tidak bersemangat dalam bekerja termasuk pelaksanaan Kepemimpinan Transformasional terhadap Kinerja Pegawai pada Bagian Keuangan Sekretariat Daerah Kabupaten Ciamis, hambatan-hambatan tersebut dikategorikan dalam beberapa point, yaitu:

1. Pemimpin belum optimal dalam memberikan perhatian khusus kepada seluruh pegawainya agar bekerja secara optimal. Hal ini ditunjukkan pegawai yang belum merasakan bentuk perhatian khusus dari pemimpin terhadap mereka.

2. Sumber daya manusia yang kurang cakap dan kurang kompeten dalam melakukan tugas menyusun laporan keuangan dikarenakan tidak semua pegawai mempunyai kemampuan dan pengetahuan untuk mengerjakan tugas tersebut

3. Tekanan kerja yaitu tekanan internal yang dapat menghambat kinerja pegawai, dan berdampak pada kondisi psikologis mereka yang akhirnya mempengaruhi terhadap hasil pekerjaan yang kurang optimal.

B. Usaha-Usaha

untuk Menanggulangi

Hambatan-

Hambatan dalam Pelaksanaan Kepemimpinan Transformasional Terhadap Kinerja Pegawai pada Bagian Keuangan Sekretariat Daerah Kabupaten Ciamis

Dilihat dari beberapa faktor yang dapat menghambat pelaksanaan kepemimpinan transformasional terhadap kinerja pegawai, dan beberapa usaha-usaha untuk menanggulangi hambatan-hambatan tersebut dalam pelaksanaan kepemimpinan transformasional terhadap kinerja pegawai pada Bagian Keuangan Sekretariat Daerah Kabupaten Ciamis yaitu :

1. Pemimpin harus selalu memberikan perhatian khusus secara pribadi kepada para pegawai dengan cara berkomunikasi dengan pegawai baik formal maupun informal.

2. Pemimpin memberikan kesempatan yang sama kepada pegawai lain untuk menyelesaikan tugas tersebut, dengan demikian para pegawai baik langsung maupun tidak langsung diberikan pelatihan, bimbingan, dan pengetahuan yang akan meningkatkan kemampuan dan pengetahuan dari para pagawai.

3. Ciptakan suasana kantor yang kondusif sehingga memberikan dampak psikologis yang baik bagi para pegawai, dan tentu saja efek positif tersebut akan meningkatkan gairah kerja para pegawai menjadi lebih baik dalam menyeselesaikan pekerjaannya.

\section{Saran}


Kepemimpinan transformasioanal merupakan salah satu faktor yang dapat meningkatkan kinerja pegawai lebih optimal pada Bagian Keuangan Sekretariat Daerah Kabupaten Ciamis dan memberikan dampak yang positif dan signifikan. Saran sekiranya dapat dilakukan dan dijadikan pertimbangan untuk mencapai hasil yang maksimal. Adapun saran-saran tersebut adalah sebagai berikut:

1. Saran Akademik

a. Memberikan pemahaman bagaimana pengaruh kepemimpinan yang dapat meningkatkan kinerja para pegawai, dan pemahaman tentang tugas pokok dan fungsi organisasi serta tugas pokok dan fungsi pegawai.

b. Hasil penelitian ini mampu memberikan peran untuk edukasi mengenai pengetahuan, pengalaman, wawasan mengenai teori-teori kepemimpinan dan kinerja, serta pengaruh kepemimpinan terhadap kinerja bagi pembaca.

\section{Saran Praktis}

a. Pemimpin harus mampu membimbing, mendorong, dan memotivasi para pegawai supaya lebih giat dan bersemangat dalam melaksanakan pekerjaan di Bagian Keuangan Sekretariat Daerah Kabupaten Ciamis. Pemimpin harus melakukan komunikasi kepada para pegawai untuk menciptakan suasana yang harmonis dan hubungan kerja yang lebih baik antara pegawai dengan pemimpin.

b. Pemimpin harus memberikan perhatian khusus kepada para pegawainya, sehingga pegawai merasa dihargai dan diperhatikan oleh pimpinan yang dapat memotivasi mereka untuk bekerja lebih baik.

c. Pemimpin harus memberikan pengetahuan, wawasan, serta pengalaman pada para pegawai di Bagian Keuangan Sekretariat Daerah Kabupaten Ciamis agar para pegawai dapat meningkatkan kemampuan dan kompetensi yang dimiliki untuk lebih optimal dalam mengerjakan pekerjaannya.

\section{Daftar Pustaka}

Buku:

Handayaningrat, Soewarno, 1980, Pengantar Studi Ilmu Administrasi dan Manajemen, Jakarta: CV Haji Masagung

Silalahi, Ulbert. 2013, Studi Tentang Ilmu Administrasi Konsep, Teori, dan Dimensi, Bandung: Sinar Baru Algensindo

Robbins, Stephen P, 1994, Teori Organisasi Struktur, Desain \& Aplikasi, Jakarta: Arcan

Hasibuan, Malayu, 2014, Manajemen Dasar, Pengertian, dan Masalah, Jakarta: Bumi Aksara

Satibi, Iwan, 2012, Manajemen Publik Dalam Perspektif Teoritik dan Empirik, Bandung: Unpas Press

Moeheriono, 2014, Pengukuran Kinerja Berbasis Kompetensi Edisi Revisi, Jakarta: PT RajaGrafindo Persada

Northouse, G Peter, 2017, Kepemimpinan Teori dan Praktik, edisi Keenam, Jakarta: PT. Indeks

Sumiati, Imas, Edisi 2005-2012, Statistik, Bandung.

Satibi, Iwan, 2011, Teknik Penulisan Skripsi, Tesis \& Desertasi, Bandung: CEPLAS (Centre For Political And Local Auntonomy)

Dokumen: 
Undang-Undang Nomor 23 tahun 2014 tentang Pemerintah Daerah

Peraturan Pemerintah Nomor 58 tahun 2005 tentang Pengelolaan Keuangan Daerah

Peraturan Bupati Nomor 37 Tahun 2016 tentang Tugas, Fungsi, dan Tata Kerja Unsur Organisasi Sekretariat Daerah
Rencana Strategis (Renstra) Sekretariat Daerah Kabupaten Ciamis Tahun 20152019

Data LAKIP Sekretaiat Daerah Kabupaten Ciamis tahun 2017

Data Kepegawaian Bagian Keuangan Sekretariat Daerah Kabupaten Ciamis tahun

2018 